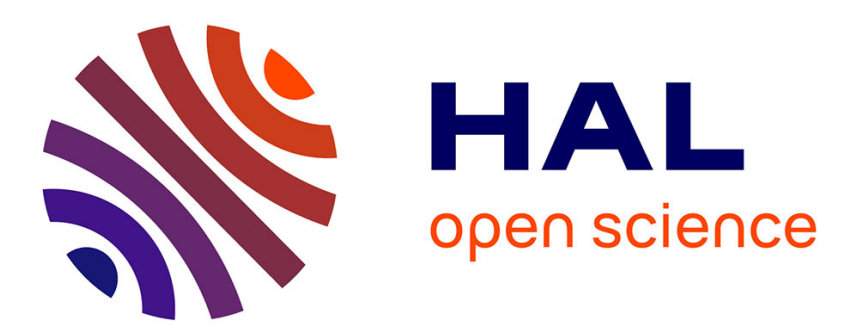

\title{
High Speed Cinematography of Cracks Spreading Under Failure of Amorphous Metallic Alloys
}

\author{
E. Tabachnikova, Y. Golovin, M. Makarov, A. Shibkov
}

\section{To cite this version:}

E. Tabachnikova, Y. Golovin, M. Makarov, A. Shibkov. High Speed Cinematography of Cracks Spreading Under Failure of Amorphous Metallic Alloys. Journal de Physique IV Proceedings, 1997, 07 (C3), pp.C3-307-C3-310. 10.1051/jp4:1997354 . jpa-00255511

\section{HAL Id: jpa-00255511 https://hal.science/jpa-00255511}

Submitted on 1 Jan 1997

HAL is a multi-disciplinary open access archive for the deposit and dissemination of scientific research documents, whether they are published or not. The documents may come from teaching and research institutions in France or abroad, or from public or private research centers.
L'archive ouverte pluridisciplinaire HAL, est destinée au dépôt et à la diffusion de documents scientifiques de niveau recherche, publiés ou non, émanant des établissements d'enseignement et de recherche français ou étrangers, des laboratoires publics ou privés. 


\title{
High Speed Cinematography of Cracks Spreading Under Failure of Amorphous Metallic Alloys
}

\author{
E.D. Tabachnikova, Y.I. Golovin*, M.V. Makarov* and A.A. Shibkov*
}

B. Verkin Institute for Low Temperature Physics \& Engineering of Ukraine Academy of Sciences, 47 Lenin's Avenue, Kharkov-164, 310164, Ukraine

* Pedagogical Institute Tambov, Tambov 392000, Russia

\begin{abstract}
The results of experimental investigation of crack propagation velocity in amorphous alloys are presented. It is shown that there exists some correlation between crack velocity and fracture mode and morphology

Résumé : Les résultats d'une recherche expérimentale sur la vitesse de propagation de fissures dans les alliages amorphes sont présentés. Il y est démontré qu'il existe une corrélation entre la vitesse de fissuration et le mode de fracture et la
\end{abstract} morphologie.

\section{INTRODUCTION}

Macroscopic plastic deformation is absent during extension of amorphous metallic alloys ribbons at low temperatures $(T \leq 300 \mathrm{~K})$. but at the same time the large $(\sim 100)$ local plastic deformation is observed in the thin band of the catastrophic shear along which the failure takes place usually at stresses close to the theoretical strength ( $-\mathrm{G} / 30$, where $\mathrm{G}$ is the shear modulus ). Besides, the work-hardening is absent in amorphous alloys, and they are absolutely thermomechanically unstable.

Under these conditions an important information can be obtained if experimental measurements of the growth kinetics of cracks are coupled with a parallel study of the failure surface morphology. Such data, that are widely and fruitfully measured in crystalline materials, are practically absent for amorphous metallic alloys

Therefore the goal of this work was experimental measurement of the kinetics of the cracks growth in amorphous alloys on the basis of $\mathrm{Ni}$ and $\mathrm{Fe}$ and observation of its influence on the character and morphology of the failure.

\section{MATERIALS AND METHODS}

$\mathrm{Ni}_{78} \mathrm{Si}_{8} \mathrm{~B}_{14}$ and $\mathrm{Fe}_{70} \mathrm{Ni}_{10} \mathrm{~B}_{20}$ amorphous alloys ribbons of the 20-30 $\mu \mathrm{m}$ thickness and $10 \mathrm{~mm}$ width (obtained by the melt quenching) were used as typical objects for the study. Samples of the $\sim 50 \mathrm{~mm}$ length were used with a narrowing (down to $5-6 \mathrm{~mm}$ ) at the middle part made by chemical etching for localizing the failure.

Samples were strained in the pulse testing machine with the electrodynamical drive [1] and the failure process was filmed with the SFR-2M camera at the rate of $2 \cdot 10^{6}$ frames per sec. Special scheme synchronized the testing machine action, pulsed light source and SFR (Fig. 1). The preliminary stretch of samples with the load of 0.5 from the failure load, removed clearances in the machine and simplified the synchronization of the failure process and filming. The duration of the dynamic stage of loading was nearly $200 \mu \mathrm{s}$ (Fig. 2) that corresponds to the loading rate of $\sim 10^{2} \mathrm{~s}^{-1}$. The length of the elastic wave under such duration of the front of the pulse exceeds repeatedly the sample length. The quasistationary regime of loading is conserved at these conditions. Surface of samples and the failure surfaces were studied by means of optical and scanning electron microscopy 


\section{RESULTS AND DISCUSSIONS}

A typical sequence of frames during the failure is shown in Fig. 3. Results of its treatment, as well as of

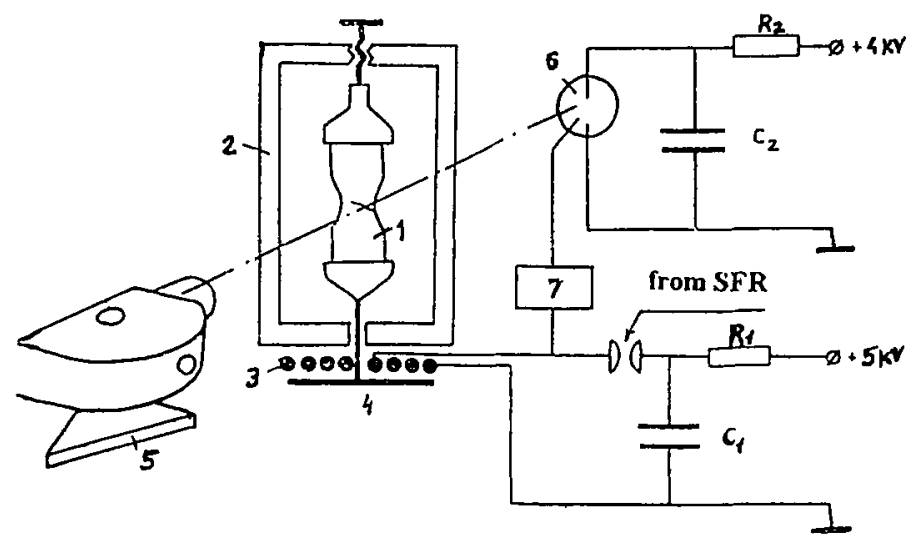

Figure 1: Scheme of the experimental device : 1- sample, 2- testing machine, 3- flat coil, 4- aluminium disk, 5- SFR. 6-pulsed lamp, 7-scheme of the synchronization and of the delay.

other films are shown in the Fig. 4. It follows from these data (and from results of dozens more filming) that the complete time of the failure is weakly varied from a sample to a sample and come to $5 \pm 1 \mu$ for both alloys. This corresponds to the value of $\sim 10^{3} \mathrm{~m} / \mathrm{s}$ for the average velocity of the main crack. But instant velocities $V$ are changed within very wide limits, at any rate, from 0 to $2.5 \cdot 10^{3} \mathrm{~m} / \mathrm{s}$. Owing to a finite time-resolution of $0.5 \mu$ s (that corresponds to the interval between neighbour frames) it is strictly speaking impossible to assert that the highest magnitude is an instant one. Actually it is also averaged in this interval and may be smaller than peak magnitudes. On the other hand, it is known from the continuum fracture mechanics that maximum velocities of cracks propagation are limited by the magnitude $\sim 0.9 \mathrm{C}$ ( $C$-the transverse elastic waves velocity) [2]. In our case it is $\sim 2.210^{3} \mathrm{~m} / \mathrm{s}$ in accord with the experiment. Highest cracks velocities in amorphous materials are limited by relativistic effects and almost independent on structure factors as in crystalline materials.

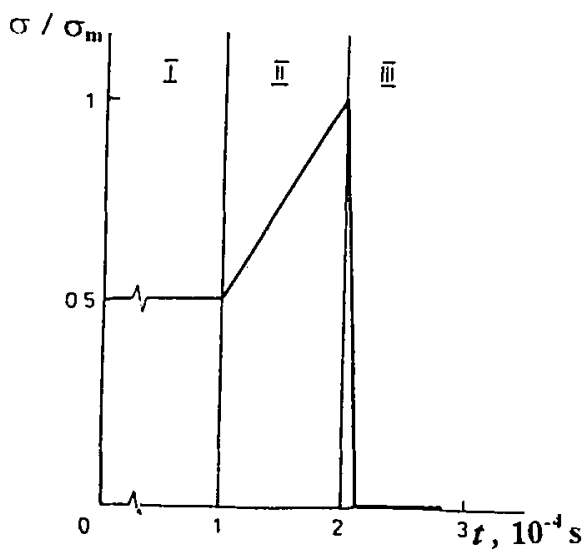

Figure 2: The time dependence of tensile stress: I-static loading. II- dynamic loading. III- the failure.

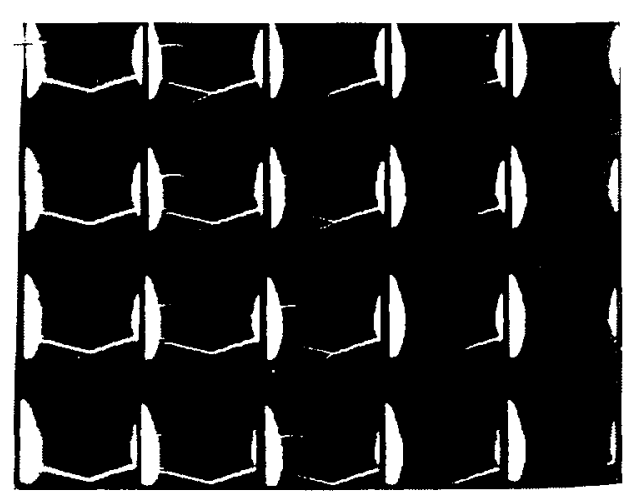

Fugure 3: Typical sequence of SFR frames during the failure of the $\mathrm{Ni}_{-8} \mathrm{Si}_{4} \mathrm{~B}_{1,}$ amoprphous alloy ribbon 
Abundant branching of cracks was observed at velocities close to limiting ones and the angle of branching was nearly $30^{\circ}$ ( Fig. 5). The velocity falls sharply at the beginning of branching and afterwards an acceleration takes place. Therefore pulsating propagation of cracks is realized with the average velocity close to 0.5 of maximum magnitude.

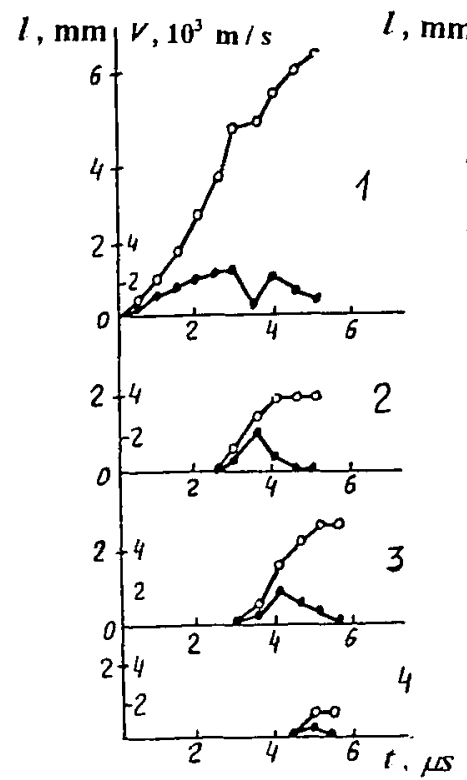

$\mathbf{a}$

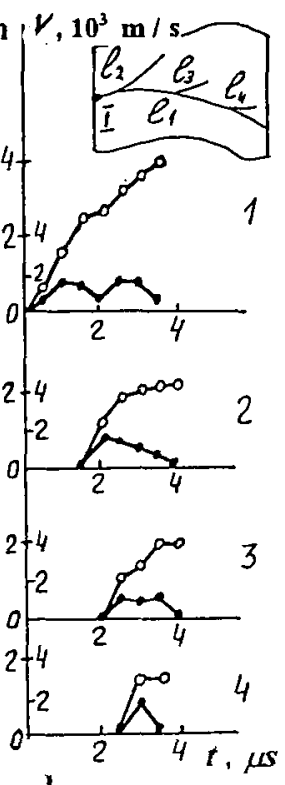

b

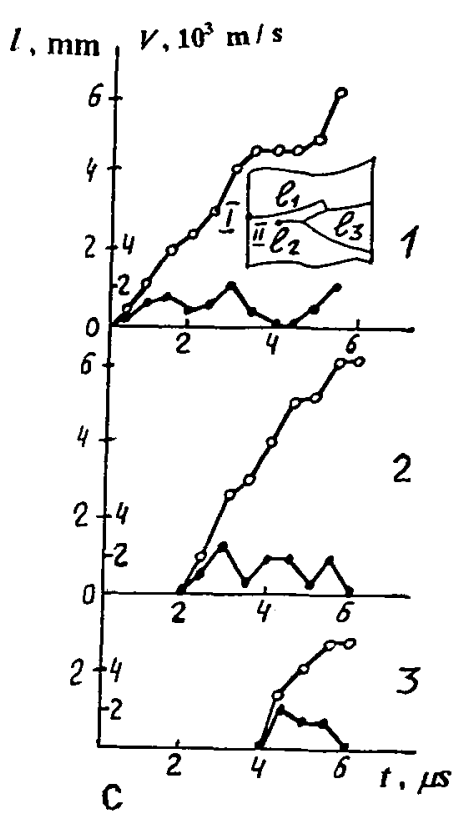

C

Figure 4: The time dependences $l(t)(0)$ and $V(t)(\bullet)$ for amorphous alloys ribbons : a) $\mathrm{Fe}_{70} \mathrm{Ni}_{10} \mathrm{~B}_{20}$; b) $\mathrm{Ni}_{78} \mathrm{Si}_{8} \mathrm{~B}_{14}$; c) $\mathrm{Ni}_{78} \mathrm{Si}_{8} \mathrm{~B}_{14}$ with cracks nucleation at several points of a sample. I- a source of the main crack; II- $\mathrm{a}$ crack source in the middle part of a sample. $1-l_{1}(t)$ and $V_{1}(t), 2-l_{2}(t)$ and $V_{2}(t) ; 3-l_{3}(t)$ and $V_{3}(t) ; 4-l_{4}(t)$ and $V_{4}(t)$.

Correlating of the fractography with plots of cracks velocities showed that during a high velocity motion the simple failure surface is observed oriented at $45^{\circ}$ to the axis of tension (corresponding to the plane of maximum shear stresses ). At this surface a "vein" pattern was observed typical of ductile shear failure.

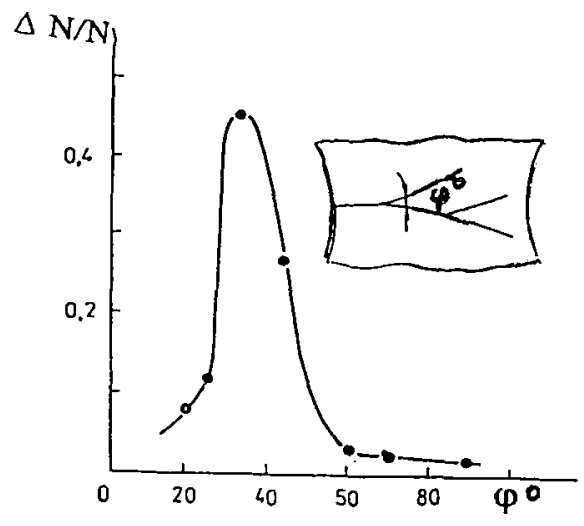

Figure 5: Distribution of the number of sccondary cracks in branching angles $\varphi^{\circ}$. 
Deceleration of the crack is accompanied by acting of two alternately active $45^{\circ}$ surfaces of the failure with a step of $\sim 50-100 \mu \mathrm{m}$ (in accordance with data of $[3,4]$ ). This region of the faceted failure surfaces contains many shear bands with the length up to $50 \mu \mathrm{m}$ which make the plastic zone. Besides, there is practically no glide bands in regions of the high velocity motion of cracks. Typically, the higher a crack velocity, the larger dimensions of facets and smaller the number of shear bands along the main crack.

Sometimes a nucleation and growth of cracks was observed at once from several points of a sample, often from opposite edges of a ribbon. Only some of them conserve their activity, probably owing to the load redistribution in a sample.

\section{CONCLUSION}

Thus, in this work the crack velocity propagation in amorphous alloys is measured directly. Cracks kinetics is limited by the elastic waves velocity as in crystalline materials. Correlating of cracks kinetics with scanning electron microscope observations of failure surfaces showed that typical peculiarities of cracks kinetics are induced by accompanying plastic deformation and the main crack branching.

\section{Acknowledgments}

The authors are grateful to Drs. K. Csach, J. Miskuf and V. Ocelik for fractographic observations.

\section{References}

[1] Finkel V.M., Golovin U.I., Sletkov A.A., Zavodskaya Laboratoria 42 (1976) 239-240.

[2] Finkel V.M., Physics of Failure (Metallurgia publishers, Moscow, 1970) 376 pp.

[3] Argon A.S. and Salama M., Mater. Sci. Eng. 23 (1976) 219-230.

[4] Ocelik V., Bengus V.Z., Diko P., Hudak O., J. Mater. Sci. Lett. 6 (1987) 1333-5. 